\title{
Affordability Linked with Subsidy: Impact of Fertilizers Subsidy on Household Welfare in Pakistan
}

\author{
Akhter Ali ${ }^{1, *}$, Dil Bahadur Rahut ${ }^{2}$ and Muhammad Imtiaz ${ }^{1}$ (D) \\ 1 International Maize and Wheat Improvement Center (CIMMYT), Islamabad 44000, Pakistan; \\ m.imtiaz@cgiar.org \\ 2 International Maize and Wheat Improvement Center (CIMMYT), El Batán, Texcoco C.P. 56237, \\ Mexico; d.rahut@cgiar.org \\ * Correspondence: akhter.ali@cgiar.org
}

Received: 18 July 2019; Accepted: 5 September 2019; Published: 20 September 2019

\begin{abstract}
Historically, the government of Pakistan has been providing subsidy on fertilizers, and the most recent subsidy program started during 2015-2016. The current study aims to estimate the impact of the fertilizers subsidy program on fertilizers application and its impact on the crops yield and household income levels using a comprehensive cross-sectional dataset collected from 850 farmers from all four major provinces of Pakistan. The fertilizer subsidy program enabled $80 \%$ of the farmers to apply recommended doses of fertilizers, and also incentivized the farmers to bring more area under cultivation. The empirical analysis has been carried out by employing the propensity score matching approach (PSM), and results indicated that fertilizer subsidy has a positive impact on crops yield and household income levels. As a result of subsidy, the wheat yields are higher in the range of $65-71 \mathrm{~kg}$ per hectare while the rice yields are higher in the range of 34-43 kg per hectare. The household income levels are higher in the range of 5671 to 6549 rupees. The fertilizer subsidy on a sustainable basis can encourage the resource-poor farmers to apply recommended doses of fertilizers and thus increase crop production, thereby contributing to the improvement in their livelihood.
\end{abstract}

Keywords: fertilizer subsidy; wellbeing; propensity score matching; Pakistan

\section{Introduction}

In Pakistan, due to highly skewed land distribution, the majority of the farmers are tenant farmers. About $80 \%$ of the farmers are small farmers, and these small farmers are not able to apply recommended doses of inputs due to poor financial conditions. Many farmers in Pakistan purchase inputs on credit (the credit inputs are always expensive as price is higher as compared to market prices) and pay back the credit at the time of crop harvest. As an effort to encourage the recommended application of inputs, the government of Pakistan has announced a subsidy on the fertilizers. The fertilizer subsidy is a great relief and support for the resource-poor farmers. Agriculture contributes about $55 \%$ of the total exports and $19.8 \%$ of the GDP of Pakistan [1]. Approximately $67 \%$ population of Pakistan lives in rural areas and are directly or indirectly dependent on agriculture for their livelihood [2]. Hence, improvement in agricultural productivity not only improves the wellbeing of the rural people, but also contributes to the overall economic growth and development of the country.

The timely application of various inputs can help to increase agricultural productivity. Productivity improvement not only depends on the timely application of the fertilizer, but also on types of fertilizer applied. The application of the farmyard manure becomes more prevalent when the prices of inorganic fertilizers are high [3]. Unfortunately, Pakistan's soils are deficient in nitrogen, phosphorus, zinc, and boron, while potassium is generally adequate in irrigated areas, but its deficiency is emerging [4]. The majority of the farmers in Pakistan also lack information on major macro and micronutrients, 
which also affects the application of nutrients. The application of fertilizers needs to be based on soil tests and recommendations of soil fertility departments. Although more fertilizer application increases the yield, the cost of production may also increase; thus, the overall profits and household income levels might not improve. Only $1 \%-2 \%$ of farmers apply potash to fruits, vegetables, and sugarcane [4]. The difference between developed countries and Pakistan is that in developed countries, the organic materials are ploughed back into the soil, whereas in Pakistan, all the straw is used for animal feed and the animals grazing in the harvested fields even eat the stubbles [5].

The input subsidy has a positive impact on household welfare [6,7]. The use of fertilizer in Pakistan has increased during the last five decades. The government of Pakistan imposed a 15\% general sales tax on all fertilizers in 2001; as a result, the prices increased. The prices of urea and diammonium phosphate (DAP) fertilizers in wheat sowing season in 2015-2016 were 1840 and 3800 Pakistani rupees, respectively, per $50 \mathrm{~kg}$ bag. As a result of the fertilizer price subsidy in 2016-2017 Government of Pakistan budget, the price of urea and DAP fertilizer dropped to 1400 and 2000, respectively, per $50 \mathrm{~kg}$ bag. In Pakistan, the majority of the farmers are small farmers with less than two hectares of land holding, and thus, the affordability to purchase fertilizers is a major challenge among these smallholder farmers. The fertilizer subsidy program can enable these farmers to apply recommended doses of fertilizers [8].

In the 2016-2017 budget, the government announced a subsidy of 20 billion Pakistani rupees to the fertilizer industry. Through the provision of gas to the fertilizer industry, the government reduced prices of urea fertilizer from 2050 rupees to 1800 rupees per $50 \mathrm{~kg}$ bag. Effective from 1 July 2016, the government decided to further reduce the price of urea to 1400 Pakistani rupee per $50 \mathrm{~kg}$ bag, and the price of DAP to 2500 Pakistani rupees per bag. The increase in prices of the fertilizers has always pushed the government to announce the subsidy so that farmers are able to apply recommended doses of fertilizers. The increase in prices of fertilizers also encourages the farmers to go for alternate options like organic and biofertilizers.

The current study has many novel aspects, such as being among the few papers that have focused on the impact of the fertilizer subsidy on household welfare in Pakistan. Secondly, to document the impact of the subsidy on household welfare, a propensity score-matching approach has been used, i.e., still quite new in the growing literature on impact evaluation $[9,10]$.

The main aim of the current paper is to estimate the impact of fertilizer subsidy on the use of various fertilizers as well as the impact of increased use of fertilizers on wheat and rice yields. The rest of the paper is organized as follows; in Section 2, a brief review of the literature is presented. In Section 3, a conceptual framework is presented, and in Section 4, data and description of variables are presented. In Section 5, empirical results are presented, and the paper concludes in Section 6 with some policy recommendations.

\section{Literature Review}

To promote the recommended application of inputs, i.e., seed, fertilizers, etc., subsidy is key (World Bank, 2007). Many studies in the past have found that partial and complete removal of subsidies to farmers can decline the use of inputs [11]. As most fertilizers are not cheap, it is important to use them efficiently and effectively to produce maximum output (Khan et al., 2010) [8]; (World Bank, 2007). In Pakistan, the farmer's application of chemical fertilizers response varies with the price [12].

Depending on the situation and conditions, the targeted subsidies work differently in different agro-ecological regions. Despite this variability, there is common agreement that the application of recommended doses of fertilizers can help to increase the crop productivity [13-15].

The government needs to focus on infrastructure improvement besides putting in place right policies, so that small, resource-poor farmers are able to apply the recommended doses of fertilizers. Few studies have also found a positive relationship between labour demand and input subsidy program [16]. 
The availability of subsidized inputs needs to be ensured to the farmers, as in some cases, the subsidized inputs benefits do not reach the farmers [17]. In addition, the subsidy program needs to target the rural poor to have maximum benefits. The input subsidy programs can help to stabilize the food prices, food security, food production, and the overall household welfare [18-20]. The input subsidy program can also help small-scale farmers find a way out of poverty.

The application of fertilizers depends upon a number of factors, especially the price (Jayne et al., 2013) [13]. A number of studies have shown that fertilizer subsidy has a positive impact on overall household welfare. In Pakistan, a number of studies have shown that as compared to support price, the fertilizer subsidy program is more beneficial.

\section{Conceptual Framework}

Farmers in Pakistan apply a number of various fertilizers to various crops. The amount of fertilizer applied depends upon the farmers' economic condition, especially the price of the fertilizer. We consider a typical farm household $[\mathrm{H}]$ that mainly applies three main types of fertilizers, i.e., urea $[\psi]$, DAP $[\zeta]$, and farmyard manure $[\varphi]$. As the application of the fertilizers is directly correlated with the price of the fertilizers, in case of subsidy $\left[P_{0}\right]$, the farmer's response varies and the following three different scenarios might arise.

In response to the fertilizer subsidy $\left[P_{0}\right]$, the household continues to apply the same amount of fertilizer, neither increase nor decrease the amount of fertilizers; in that case, the fertilizer application can be presented as follows

$$
P_{0}=[\psi, \zeta, \varphi]
$$

The second scenario can be that as a result of subsidy $\left[P_{0}\right]$, the household increases the amount of the fertilizers, as presented in the equation below

$$
P_{0}=\left[\psi_{1}, \zeta_{1}, \varphi_{1}\right]
$$

The third scenario that is highly unlikely to occur is that as a result of subsidy, the household decreases the application of the fertilizers, as presented in the equation below

$$
P_{0}=\left[\psi_{0}, \xi_{0}, \varphi_{0}\right]
$$

As a result of subsidy, the farmer's decision to increase, decrease, or retain the amount of the fertilizers needs to be determined, and the impact of this change in the dose of the fertilizer on household welfare also needs to be estimated. As a result of subsidy, in most cases, farmers increase the amount of the fertilizer applied and in some cases, keep the same or decrease the amount based upon soil fertility department recommendation. To asses the factor influencing increased fertilizer application, we estimated a Probit model and a Tobit model for the intensity/quantity of application. We investigated the impact of the subsidy on crops yield and household income levels using a propensity score matching approach. For propensity score matching approach (PSM), it is generally recommended to estimate two different matching algorithms viz nearest neighbor matching (NNM) and kernel-based matching (KBM) [21,22]. Propensity score matching follows that the expected treatment effect for the treated population is of primary importance. This effect may be given as:

$$
\left.\tau\right|_{I=1}=E(\tau \mid I=1)=E\left(R_{1} \mid I=1\right)-E\left(R_{0} \mid I=1\right)
$$

where $\tau$ is the average treatment effect for the treated (ATT).The propensity score matching model (PSM) can be used to account for sample selection bias in the absence of experimental data. The PSM is the conditional probability that a farmer applies fertilizer, given pre-fertilizer application characteristics. To create the condition of a randomized experiment, the PSM employs the unconfoundedness assumption, also known as the conditional independence assumption (CIA), which implies that once $\mathrm{Z}$ 
is controlled for, fertilizer application is random and uncorrelated with the outcome variables. The PSM can be expressed as:

$$
p(Z)=\operatorname{Pr}\{I=1 \mid Z\}=E\{I \mid Z\}
$$

where $I=\{0,1\}$ is the indicator for application of the fertilizer and $Z$ is the vector of pre-fertilizer application characteristics. The conditional distribution of $Z$, given $p(Z)$, is similar in both groups of farmers who apply and do not apply fertilizer. After estimating the propensity scores, the average treatment effect for the treated (ATT) can then be estimated as:

$$
\tau=E\left\{R_{1}-R_{0} \mid I=1\right\}=E\left\{E\left\{R_{1}-R_{0} \mid I=1, p(Z)\right\}\right\}=E\left\{E\left\{R_{1} \mid I=1, p(Z)\right\}-E\left\{R_{0} \mid I=0, p(Z)\right\} \mid I=0\right\}
$$

Propensity score matching rests on two strong assumptions, i.e., the conditional independence assumption and the common support condition.

\section{Data and Description of Variables}

The data were collected from 850 households in four provinces of Pakistan through a primary field survey. A team of well-trained enumerators managed the data collection, who pilot tested the instrument before the survey. The survey instrument was designed to collect information on household and farm level characteristics. The detailed information regarding fertilizer applications, specifically the impact of recent subsidy on fertilizer application as well as the subsequent impact on crops yield and household income, was documented. The Table 1 shows the distribution of the sample $-38 \%$ of the sampled farmers were from the Punjab, 25\% from Sindh, 25\% from KPK, and 12\% from Balochistan province. The district-wise sample across Pakistan is presented below in Figure 1.

Table 1. Province-wise sample size.

\begin{tabular}{cc}
\hline Province & Sample in Percentage \\
\hline Baluchistan & $12 \%$ \\
Sindh & $25 \%$ \\
KPK & $25 \%$ \\
Punjab & $38 \%$ \\
Total & 850 \\
\hline
\end{tabular}

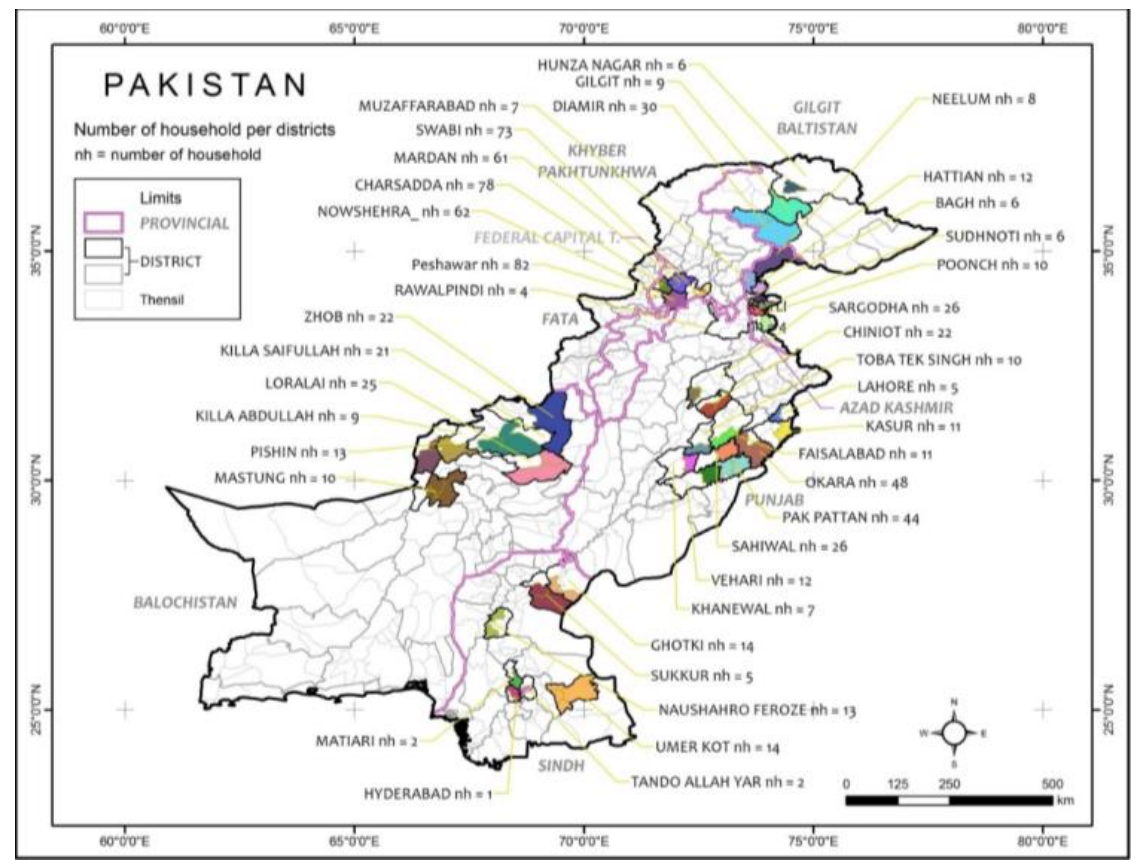

Figure 1. District-wise sample size across Pakistan. 
The mean values and standard deviation of the variables along with variable description are presented in Table 2. The mean age of the farmers was 43 years, and the farming experience was 21 years, highlighting the fact that the farmers are older individuals with substantial experience in agriculture. The household size was 12 , and the number of adult male and female is almost same, i.e., three male and three female per household, which means that the farm household has ample family labour for farming. The average years of schooling of the farmer stand at eight years, which is an indication that farmers have obtained good formal education to learn and understand new technology and government policy.

Table 2. Data and description of variables.

\begin{tabular}{|c|c|c|c|}
\hline Variable & Description & Mean & Std. Dev. \\
\hline \multicolumn{4}{|c|}{ Demographic and human capital } \\
\hline Age of farmer & Age of the farmer in number of years & 43.22 & 10.81 \\
\hline Farming experience & Farming experience of the farmer in number of years & 20.83 & 10.18 \\
\hline Household size & Number of total family members living in the household & 12.14 & 4.36 \\
\hline Adult male & Numbers of adult male living in the household & 2.97 & 1.42 \\
\hline Adult female & Numbers of adult female living in the household & 2.97 & 1.72 \\
\hline Education & Education of the farmer in number of years & 8.16 & 4.00 \\
\hline \multicolumn{4}{|c|}{ 20 } \\
\hline Land owned & Average number of acres owned by the farmer & 25.37 & 39.47 \\
\hline Land rental cost & Land rental cost in Pakistani rupees & $33,716.2$ & 7081.8 \\
\hline Slope & 1 if the slope of all plots is same, 0 otherwise & 0.56 & 0.49 \\
\hline Legumes & 1 if legumes is used in crop rotation, 0 otherwise & 0.06 & 0.25 \\
\hline Owner fertilizer share & Owner share in fertilizer application & 0.50 & 0.13 \\
\hline Tenant fertilizer Share & Tenant share in fertilizer application & 0.50 & 0.13 \\
\hline \multicolumn{4}{|l|}{ Farm assets } \\
\hline Tractor & 1 if the household owns a tractor, 0 otherwise & 0.66 & 0.47 \\
\hline Trolley & 1 if the household owns a trolley, 0 otherwise & 0.50 & 0.50 \\
\hline Zt drill & 1 if the household owns a $\mathrm{Zt}$ drill, 0 otherwise & 0.27 & 0.44 \\
\hline Tubewell & 1 if the household owns a tube well, 0 otherwise & 0.66 & 0.47 \\
\hline MB plough & 1 if the household owns MB plough, 0 otherwise & 0.47 & 0.50 \\
\hline Rotavator & 1 if the household owns a rotavator, 0 otherwise & 0.51 & 0.50 \\
\hline Laser & 1 if the household owns a laser land leveling, 0 otherwise & 0.05 & 0.22 \\
\hline Thresher & 1 if the household owns a thresher, 0 otherwise & 0.41 & 0.49 \\
\hline Ridger & 1 if the household owns a ridger, 0 otherwise & 0.48 & 0.50 \\
\hline Planker & 1 if the household owns a planker, 0 otherwise & 0.43 & 0.49 \\
\hline Reaper & 1 if the household owns a reaper, 0 otherwise & 0.35 & 0.48 \\
\hline Combine Harvester & 1 if the household owns a combine harvester, 0 otherwise & 0.12 & 0.32 \\
\hline \multicolumn{4}{|l|}{ Household durable assets } \\
\hline Car & 1 if the household owns a car, 0 otherwise & 0.40 & 0.49 \\
\hline Bicycle & 1 if the household owns a bicycle, 0 otherwise & 0.45 & 0.50 \\
\hline Motorcycle & 1 if the household owns a motorcycle, 0 otherwise & 0.83 & 0.37 \\
\hline Washing Machine & 1 if the household owns a washing machine, 0 otherwise & 0.66 & 0.47 \\
\hline Refrigerator & 1 if the household owns a refrigerator, 0 otherwise & 0.78 & 0.41 \\
\hline $\mathrm{AC}$ & 1 if the household owns an AC, 0 otherwise & 0.20 & 0.40 \\
\hline Room Cooler & 1 if the household owns a room cooler, 0 otherwise & 0.50 & 0.50 \\
\hline Iron & 1 if the household owns an iron, 0 otherwise & 0.85 & 0.35 \\
\hline Microwave & 1 if the household owns a microwave, 0 otherwise & 0.12 & 0.32 \\
\hline TV & 1 if the household owns a TV, 0 otherwise & 0.77 & 0.42 \\
\hline Cart & 1 if the household owns a Cart, 0 otherwise & 0.33 & 0.47 \\
\hline Generator & 1 if the household owns a generator, 0 otherwise & 0.09 & 0.29 \\
\hline UPS & 1 if the household owns a UPS, 0 otherwise & 0.25 & 0.43 \\
\hline \multicolumn{4}{|c|}{ Access to facilities and infrastructure } \\
\hline Metal road & 1 if the household have access to metal road, 0 otherwise & 0.85 & 0.35 \\
\hline Basic health unit & $\begin{array}{l}1 \text { if the household has access to the basic health unit, } 0 \\
\text { otherwise }\end{array}$ & 0.68 & 0.46 \\
\hline School & 1 if the household has access to school, 0 otherwise & 0.87 & 0.32 \\
\hline Transport & 1 if the household has access to transport, 0 otherwise & 0.91 & 0.27 \\
\hline Pesticide & 1 if the household has access to pesticide dealer, 0 otherwise & 0.77 & 0.42 \\
\hline Water supply & 1 if the household has access to water supply, 0 otherwise & 0.48 & 0.50 \\
\hline Post office & 1 if the household has access to the post office, 0 otherwise & 0.50 & 0.50 \\
\hline Credit facility & 1 if the household has access to the credit facility, 0 otherwise & 0.11 & 0.31 \\
\hline Extension & 1 if the household has access to extension facility, 0 otherwise & 0.20 & 0.40 \\
\hline \multicolumn{4}{|c|}{ 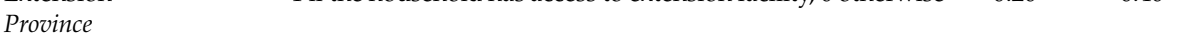 } \\
\hline Punjab & 1 if the respondent is from Punjab province, 0 otherwise & 0.38 & 0.26 \\
\hline Sindh & 1 if the respondent is from Sindh province, 0 otherwise & 0.25 & 0.19 \\
\hline KPK & 1 if the respondent is from KPK province, 0 otherwise & 0.25 & 0.17 \\
\hline Balochistan & 1 if the respondent is from Balochistan province, 0 otherwise & 0.12 & 0.09 \\
\hline
\end{tabular}


The average landholding per household was about 25 acres, and the average current land rental charge was 33,716 Pakistani rupees per year. The land rent varied from area to area depending upon the soil fertility, the slope of the soil, and land location. About $56 \%$ of the farmers reported their land to be completely flat. From 850 farm households, a significantly low number of farmers included legumes in crop rotation (only $6 \%$ of the farmers).

Farm assets are essential tools for the farm household to cultivate the land; hence, we obtained the information on farm assets. The tractor is important for managing the farm and transportation, and the data show that $66 \%$ of the households owned a tractor and $50 \%$ owned a trolley. Approximately $47 \%$ of the households owned a moldbold(MB ) plough, $51 \%$ owned a rotavator, $41 \%$ owned a thresher, $48 \%$ owned a ridger, $35 \%$ owned a reaper, only $12 \%$ owned a combine harvester, and $5 \%$ owned a laser land leveling machine. From the analysis of the farm asset ownership, we can conclude that the sampled farmer have diverse and ample farm equipment.

Transportation is an important means to commute to the market, and our data show that about $40 \%$ owned a car, $83 \%$ owned a motorcycle, and $45 \%$ owned a bicycle. About $77 \%$ of the households owned a television, $66 \%$ owned a washing machine, $78 \%$ owned a refrigerator, $20 \%$ had an air conditioner; $50 \%$ had room cooler ownership, only $9 \%$ had a generator, and $25 \%$ had UPS. Thus, the surveyed farmers have adequate transportation facilities and a significantly large number of farmers own television, which provides access to information on agricultural technology, weather information, and policy.

About $85 \%$ of the households had access to metal road, and $91 \%$ had access to transport facilities. Approximately $68 \%$ reported to have access to the basic health unit, $87 \%$ of the villages had access to the school facility, and $50 \%$ had access to the post office. Access to agricultural support and credit facilities seems limited; the result shows that only $20 \%$ had access to agricultural extension services and $11 \%$ had access to credit facilities. Approximately $77 \%$ had a pesticide dealer in the village, and $48 \%$ had access to water supply. In the tenancy arrangements, the owners and tenants have equal share in fertilizer application, meaning they share the cost as well as labour charges in fertilizer application.

\section{Empirical Results}

\subsection{Fertilizer Application}

The details about fertilizer information and application are presented in Tables 3 and 4 . Awareness about micro and macronutrients is crucial for the farm household to make a rational decision on fertilizer application. The results show that $85 \%$ of the farmers had information about the macronutrient and about $74 \%$ had information about micronutrients. After the implementation of the fertilizer subsidy program, $61 \%$ of the households increased fertilizer dose application, but only $14 \%$ of the farm households applied fertilizer as per the recommendation based on the soil fertility test as both over and under application reduces crop yields. Most importantly, $89 \%$ of the farmers felt that price reduction has a positive impact on crops yield and household income levels.

Table 3. Details about fertilizer information and application.

\begin{tabular}{|c|c|c|c|}
\hline Variable & Description & Mean & Std. Dev \\
\hline Macronutrient & 1 if the farmer have information about macronutrient, 0 otherwise & 0.85 & 0.35 \\
\hline Micronutrient & 1 if the household has information about micronutrient, 0 otherwise & 0.74 & 0.43 \\
\hline Increased fertilizer dose & 1 if the farmers have increased fertilizer dose as a result of subsidy, 0 otherwise & 0.61 & 0.49 \\
\hline Price reduction impact & 1 if the farmers think that fertilizer price reduction has a positive impact, 0 otherwise & 0.89 & 0.31 \\
\hline All plots fertility & 1 if all the plots have same fertility, 0 otherwise & 0.71 & 0.45 \\
\hline Applied fertilizer according to soil test & 1 if the farmers have applied fertilizers according to soil test, 0 otherwise & 0.14 & 0.35 \\
\hline Urea price & Average price of urea in rupees & 1836 & 69.39 \\
\hline DAP price & Average price of DAP in rupees & 3816 & 96.85 \\
\hline Potash price & Average price of Potash in rupees & 2103 & 1567 \\
\hline FYM price & Average price of farmyard manure & 3427 & 1911 \\
\hline FYM application & 1 if the farmer has applied farmyard manure, 0 otherwise & 0.91 & 0.23 \\
\hline
\end{tabular}


Table 4. Crop-wise amount of fertilizer increase because of subsidy.

\begin{tabular}{cccc}
\hline Crop & $\begin{array}{c}\text { Increased Amount of } \\
\text { Urea (kgs/hectare) }\end{array}$ & $\begin{array}{c}\text { Increased Amount of } \\
\text { DAP (kgs/hectare) }\end{array}$ & $\begin{array}{c}\text { Increased Amount of Other } \\
\text { Fertilizers (kgs/hectare) }\end{array}$ \\
\hline Wheat & 12.34 & 15.16 & 5.28 \\
Maize & 10.41 & 13.42 & 4.05 \\
Rice & 6.23 & 10.85 & 5.69 \\
Sugarcane & 5.07 & 8.53 & 2.14 \\
Cotton & 14.36 & 12.27 & 3.61 \\
\hline
\end{tabular}

As expected, analysis shows a considerable decrease in the price of fertilizer after the subsidy. The urea price after the subsidy was PKR 1836 and the DAP price was PKR 3816 and potash was PKR 2103. Although the cost of farmyard manure was as high as PKR 3427 per trolley, $91 \%$ of the farmers have applied farmyard manure to enhance the soil fertility. The fertilizer subsidy program has resulted in a reduction in fertilizer prices in the range of $30-40 \%$.

\subsection{Factor Influencing the Increase in Fertilizer Application}

About $61 \%$ of the farmers increased the use of fertilizers after the subsidy program. As the dependent variable is the binary choice ( 1 if the farmers increased the application of fertilizers, otherwise zero), we used a probit model to estimate the determinants of increase in fertilizer after the subsidy program, and the result is reported in Table 5 .

Table 5. Determinants of the increase in fertilizer dose (probit estimates).

\begin{tabular}{|c|c|c|}
\hline Variable & Coefficient & $T$-Values \\
\hline \multicolumn{3}{|l|}{ Demographic } \\
\hline Age & $0.12 * *$ & 2.20 \\
\hline Number of male working in the farm & $0.11 * *$ & 2.32 \\
\hline Years of schooling & $0.18 *$ & 1.71 \\
\hline \multicolumn{3}{|l|}{ Physical assets } \\
\hline Land owned in acres & $0.08^{* * *}$ & 3.16 \\
\hline Slope of the land (dummy) & $0.01^{*}$ & 1.73 \\
\hline \multicolumn{3}{|l|}{ Household durable asset } \\
\hline Microwave (dummy) & $-0.14 *$ & 1.66 \\
\hline Television (dummy) & $0.02 * * *$ & 3.07 \\
\hline Generator (dummy) & 0.02 & 1.36 \\
\hline \multicolumn{3}{|l|}{ Farm assets } \\
\hline Tractor (dummy) & $0.10 * *$ & 2.04 \\
\hline Cart (dummy) & $0.01 *$ & 1.72 \\
\hline \multicolumn{3}{|l|}{ Access to facilities } \\
\hline Metal Road (dummy) & -0.16 & -0.89 \\
\hline Water supply (dummy) & 0.05 & 1.27 \\
\hline Post office (dummy) & -0.03 & -1.46 \\
\hline Transport (dummy) & 0.29 & 1.45 \\
\hline Credit facility (dummy) & $0.01 *$ & 1.84 \\
\hline Agri. Extension (dummy) & $0.11 *$ & 1.75 \\
\hline \multicolumn{3}{|l|}{ Province } \\
\hline Punjab (dummy) & $0.03 * *$ & 1.95 \\
\hline Sindh (dummy) & -0.01 & 1.52 \\
\hline KPK (dummy) & 0.03 & 1.64 \\
\hline Constant & $0.15^{* * *}$ & 2.65 \\
\hline Pseudo R-square & \multicolumn{2}{|c|}{0.54} \\
\hline LR Chi-Square & \multicolumn{2}{|c|}{367.25} \\
\hline PRob $>$ Chi Square & \multicolumn{2}{|c|}{0.000} \\
\hline Number of Observations & \multicolumn{2}{|c|}{850} \\
\hline
\end{tabular}

Note: Results are significant at ${ }^{* * * * * *}, 1 \%, 5 \%$, and $10 \%$ levels, respectively. 
The age coefficient was positive and significant, indicating that older farmers applied more fertilizers after the subsidy as compared to young farmers. The number of household's males working at the farm coefficient was positive and significant, indicating that family labour can more efficiently facilitate the fertilizer application process. The coefficient of years of schooling was also positive and significant, indicating that subsidy resulted in increases in fertilizer application for farmers with a higher level of education, which shows that the farmers with a higher level of education took advantage of the subsidy program and maximized the opportunities.

The landholding coefficient was positive and highly significant at $1 \%$ level of significance, indicating that farmers with higher landholding increased the application of the fertilizers. As the farmers with large landholding are comparatively more affluent households with access to information and extension services, they are able to obtain and increase the fertilizer application in their farm. The slope coefficient is also positive and highly significant at $10 \%$ level of significance.

The household and farm assets like television and cart ownership were positive and significant, while the coefficient of the generator ownership was positive but non-significant. The tractor ownership was positive and significant at $5 \%$ level of significance, indicating that households owning a tractor were applying higher doses of fertilizers. This shows that wealthier households increased the fertilizer application.

The coefficient of the access to facilities variables such as metal road, water supply, transportation, and the post office was non-significant. The coefficient of the agricultural extension services dummy was positive and significant at $10 \%$ level of significance indicating that farmers with contact to agricultural extension services increased the fertilizers application. The access to credit facility was positive and significant, indicating that households with access to credit facility increased the doses of fertilizers.

The provincial dummies were also included in the model to control for the effect of the location, which is not captured by the household and demographic variables. The value of pseudo-R-square was 0.54 , indicating that $54 \%$ variation in the independent variable is due to independent variables included in the model. The LR Chi-square was positive and highly significant at $1 \%$ level of significance.

\subsection{Factor Influencing the Intensity of Fertilizer Application}

We also investigated the factor influencing the intensity/quantity of fertilizer applied by the farm household using multivariate tobit model and results are presented in Table 6. The dependent variable is the share of the amount of the different fertilizers applied per hectare, i.e., DAP, urea, farmyard manure, and others; as the share of the different types of fertilizer is mutually inclusive, the multivariate Tobit model has been estimated.

The age coefficient was positive and highly significant for the inorganic fertilizers like DAP and Urea while negative and significant for the organic and other fertilizers, indicating that young farmers mostly apply organic fertilizers while the experienced farmers mostly apply inorganic fertilizers. The coefficient of the education was positive and significant for all the fertilizers, indicating that educated farmers mostly apply more fertilizers and vice versa. The number of male members working on the farm was also positive and significant for all kinds of fertilizer, indicating that households with a higher number of male family members are likely to apply more fertilizer.

The landholding coefficient was negative and significant for the application of the farmyard manure and other fertilizer, indicating that farmers with large landholdings mostly apply less farmyard manure and other fertilizer. This may be because farmers with large landholding produce a surplus for market while farmers with small landholdings produce solely for self-consumption and are likely to grow crops using organic fertilizer. Furthermore, farming a large amount of land requires more fertilizer and the cost of organic fertilizer is high, and it may be expensive to use more organic fertilizer. The coefficient of the slope dummy was negative and significant for the application of all fertilizer, which may be because the marginal rate of return for sloppy land is less. 
Table 6. Determinants of the amount of fertilizer application (multivariate tobit model).

\begin{tabular}{|c|c|c|c|c|}
\hline Variable & DAP & Urea & Farmyard Manure & Others \\
\hline \multicolumn{5}{|l|}{ Demographic } \\
\hline Age & $0.02 * * *(2.81)$ & $0.03^{* * *}(3.26)$ & $-0.02 *(-1.74)$ & $-0.01^{* *}(-2.51)$ \\
\hline $\begin{array}{l}\text { Number of male } \\
\text { working at farm }\end{array}$ & $0.02^{* * *}(2.60)$ & $0.01 *(1.82)$ & $0.03^{* *}(1.99)$ & $0.02 *(1.78)$ \\
\hline Education & $0.01^{* * *}(2.03)$ & $0.02^{* *}(2.15)$ & $0.01^{* * *}(2.62)$ & $0.03(1.09)$ \\
\hline \multicolumn{5}{|l|}{ Physical assets } \\
\hline Land holding & $-0.01(-1.53)$ & $-0.02(-1.27)$ & $-0.03^{* *}(2.31)$ & $-0.04 *(-1.83)$ \\
\hline Slope of the land & $-0.01^{*}(-1.76)$ & $-0.02 * *(-2.36)$ & $-0.01 *(-1.95)$ & $-0.03(-1.26)$ \\
\hline Television & $0.02 * *(1.98)$ & $0.03^{* * *}(2.63)$ & $0.01^{* *}(2.20)$ & $0.02 *(1.95)$ \\
\hline Tractor & $0.01(1.22)$ & $0.02 * * *(2.68)$ & $0.01^{* *}(2.27)$ & $0.03^{* * *}(3.10)$ \\
\hline Cart & $0.01 * * *(3.64)$ & $0.02 * *(2.15)$ & $0.01^{* * *}(3.19)$ & $0.02 * *(2.36)$ \\
\hline \multicolumn{5}{|l|}{ Access to facilities } \\
\hline Agri. Extension & $0.03^{* * *}(3.54)$ & $0.01 *(1.75)$ & $0.01^{* *}(2.09)$ & $0.02(1.36)$ \\
\hline Credit facility & $0.02 *(1.73)$ & $0.03^{* * *}(3.16)$ & $-0.01^{* *}(-2.04)$ & 0.02 (1.27) \\
\hline Metal Road & $0.01 *(1.69)$ & $0.02^{* *}(2.01)$ & $-0.03 *(-1.87)$ & $0.01 *(1.89)$ \\
\hline Transport & $0.02 *(1.91)$ & $0.01 * *(2.14)$ & $0.03(1.62)$ & $0.02 *(1.72)$ \\
\hline Water supply & $0.01^{* *}(2.08)$ & $0.02 * *(2.19)$ & $0.03(1.34)$ & $0.01(1.29)$ \\
\hline Post office & $0.01(1.13)$ & $0.02(1.44)$ & $0.03(1.23)$ & $0.02(1.33)$ \\
\hline \multicolumn{5}{|l|}{ Province } \\
\hline Punjab & $0.01(1.34)$ & $0.02(1.52)$ & $0.03(1.46)$ & $0.01(1.30)$ \\
\hline Sindh & $0.03(0.83)$ & $0.03(1.36)$ & $0.01(1.29)$ & $0.02(1.43)$ \\
\hline KPK & $0.01(0.57)$ & $0.02(1.29)$ & $0.02(1.24)$ & $0.03(1.22)$ \\
\hline Constant & \multicolumn{4}{|c|}{$0.03^{* * *}(2.75)$} \\
\hline $\begin{array}{l}\text { Cross Equations } \\
\text { Correlations }\end{array}$ & $\begin{array}{c}\text { Rho12 } 0.42 * * * \\
\text { (3.17) }\end{array}$ & Rho13 $0.26 *(1.78)$ & $\begin{array}{c}\text { Rho14 } 0.25^{* * *} \\
(2.95)\end{array}$ & Rho23 $0.38^{* *}(2.06)$ \\
\hline $\begin{array}{l}\text { Cross Equations } \\
\text { Correlations }\end{array}$ & $\begin{array}{c}\text { Rho24 } \\
0.19 *(1.80)\end{array}$ & \multicolumn{3}{|l|}{ Rho34 $0.24^{* *}(2.03)$} \\
\hline Pseudo R-square & \multicolumn{4}{|c|}{0.35} \\
\hline LR Chi Square & \multicolumn{4}{|c|}{367.59} \\
\hline PRob $>$ Chi Square & \multicolumn{4}{|c|}{0.000} \\
\hline $\begin{array}{l}\text { Number of } \\
\text { Observations }\end{array}$ & \multicolumn{4}{|c|}{850} \\
\hline
\end{tabular}

The household and farm assets such as television, tractor, and cart were positive and significant for both organic and inorganic fertilizer, indicating that the more affluent households apply more fertilizer as they have the capacity to invest more on inputs such as fertilizer.

The institutional variable such as access to the credit facility and extension services are positive and significant indicating that farmers with more institutional support mostly apply higher quantities of fertilizers. Access to infrastructure such as metal road, transport, water supply was positive and significant for all types of fertilizer, indicating that infrastructure plays an important role in input use.

The district dummies were also included to account for the regional heterogeneity, and we did not find a significant difference in fertilizer application across different districts. The LR chi-square indicates the robustness of the variables included in the model.

\subsection{Impact of Fertilizer Application on Crop Yield and Household Income}

The impact of an increase in fertilizer use as a result of fertilizer subsidy on wheat and rice crops yield as well as household income levels was analyzed using two different matching algorithms, i.e., nearest neighbor matching (NNM) and kernel-based matching (KBM) and the results are presented in Table 7. The nearest neighbor matching matches with the similar nearest neighbour in the opposite group while the kernel-based matching takes the weighted average of all the nonparticipants and then matches. 
Table 7. Impact of the fertilizer subsidy on crops yield and household income levels.

\begin{tabular}{|c|c|c|c|c|c|c|c|}
\hline $\begin{array}{c}\text { Matching } \\
\text { Algorithms }\end{array}$ & Outcome & $\begin{array}{l}\text { Caliper/Band } \\
\text { Width }\end{array}$ & ATT & $T$-Values & $\begin{array}{c}\text { Critical Level } \\
\text { of Hidden Bias }\end{array}$ & $\begin{array}{l}\text { Numbers } \\
\text { of Treated }\end{array}$ & $\begin{array}{l}\text { Numbers } \\
\text { of Control }\end{array}$ \\
\hline \multirow{3}{*}{ NNM } & $\begin{array}{c}\text { Wheat Yield } \\
\text { (Kgs/acre) }\end{array}$ & 0.01 & $65.37^{* * *}$ & 2.71 & $1.35-1.40$ & 437 & 289 \\
\hline & $\begin{array}{l}\text { Rice Yield } \\
\text { (Kgs/acre) }\end{array}$ & 0.05 & $34.76^{* *}$ & 2.33 & $1.10-1.15$ & 437 & 289 \\
\hline & $\begin{array}{l}\text { Household } \\
\text { Income (PKR) }\end{array}$ & 0.03 & 5671 & 1.34 & - & 437 & 289 \\
\hline \multirow{3}{*}{$\mathrm{KBM}$} & $\begin{array}{c}\text { Wheat Yield } \\
\text { (Kgs/acre) }\end{array}$ & 0.01 & 71.36 * & 1.82 & $1.45-1.50$ & 465 & 306 \\
\hline & $\begin{array}{l}\text { Rice Yield } \\
\text { (Kgs/acre) }\end{array}$ & 0.02 & 43.61 ** & 2.04 & $1.30-1.35$ & 465 & 306 \\
\hline & $\begin{array}{c}\text { Household } \\
\text { Income (PKR) }\end{array}$ & 0.03 & $6549 *$ & 1.84 & $1.45-1.50$ & 465 & 306 \\
\hline
\end{tabular}

Note: ATT stands for the average treatment effect for the treated. The results are significant at ${ }^{* * *}, * * * 1 \%, 5 \%$, and $10 \%$ levels, respectively.

The impact of fertilizer on wheat production was positive and significant, as wheat is an important food security crop and increases in wheat production also ensure the food security and thus political stability. The ATT (Average Treatment affect for the Treated) results for the wheat yield were in the range of $65-71 \mathrm{~kg}$ per hectares, indicating that fertilizer subsidy increased the wheat yield. Similarly, the ATT results for the rice yields were higher in the range of $34-43 \mathrm{~kg}$ per hectare, indicating that subsidy has a positive impact on rice production. The ATT results for the household income levels were also positive and significant, indicating that as a result of fertilizer subsidy, the household income levels are also higher. From the empirical findings, we can clearly conclude that fertilizer has a positive and significant impact on household welfare in Pakistan. However, in Pakistan, the farmyard manure and leguminous crops are very much missing in the system, and from an environmental conservation viewpoint, these need to be promoted [23,24].

The quality of matching was tested by employing a number of matching algorithms, i.e., median absolute bias before and after matching, joint significance of covariates before and after matching, and value of R-square before and after matching. The results of the matching quality are presented in Table 8 and Figure 2.

Table 8. Indicators of covariates balancing before and after matching.

\begin{tabular}{|c|c|c|c|c|c|c|c|c|}
\hline $\begin{array}{l}\text { Matching } \\
\text { Algorithms }\end{array}$ & Outcome & $\begin{array}{c}\text { Median } \\
\text { Absolute } \\
\text { Bias before } \\
\text { Matching }\end{array}$ & $\begin{array}{l}\text { Median } \\
\text { Absolute } \\
\text { Bias after } \\
\text { Matching }\end{array}$ & $\begin{array}{l}\text { Percentage } \\
\text { Bias } \\
\text { Reduction }\end{array}$ & $\begin{array}{l}\text { Value of } \\
\text { R-Square } \\
\text { before } \\
\text { Matching }\end{array}$ & $\begin{array}{c}\text { Value of } \\
\text { R-Square } \\
\text { after } \\
\text { Matching }\end{array}$ & $\begin{array}{c}\text { P-Value of } \\
\text { Joint } \\
\text { Significance } \\
\text { of Covariate } \\
\text { before } \\
\text { Matching }\end{array}$ & $\begin{array}{c}P \text {-Value of } \\
\text { Joint } \\
\text { Significance } \\
\text { of Covariates } \\
\text { after } \\
\text { Matching }\end{array}$ \\
\hline \multirow[t]{2}{*}{ NNM } & $\begin{array}{c}\text { Wheat Yield } \\
\text { (Kos/acre) }\end{array}$ & 24.18 & 4.67 & 81 & 0.357 & 0.002 & 0.001 & 0.446 \\
\hline & $\begin{array}{l}\text { Household } \\
\text { Income }\end{array}$ & 17.03 & 5.11 & 70 & 0.418 & 0.002 & 0.003 & 0.408 \\
\hline \multirow[t]{3}{*}{ KBM } & Wheat Yield & 25.38 & 6.11 & 76 & 0.433 & 0.002 & 0.003 & 0.372 \\
\hline & Rice Yield & 24.16 & 5.27 & 78 & 0.650 & 0.001 & 0.002 & 0.535 \\
\hline & $\begin{array}{l}\text { Household } \\
\text { Income }\end{array}$ & 24.55 & 6.32 & 74 & 0.367 & 0.002 & 0.003 & 0.628 \\
\hline
\end{tabular}

The median absolute bias and the value of R-square were significantly reduced after matching while the p-value of joint significance increased after matching, indicating that the matching was perfect. Figure 2 indicates that PSM has been implemented quite effectively, and the two groups are very much similar to each other. 


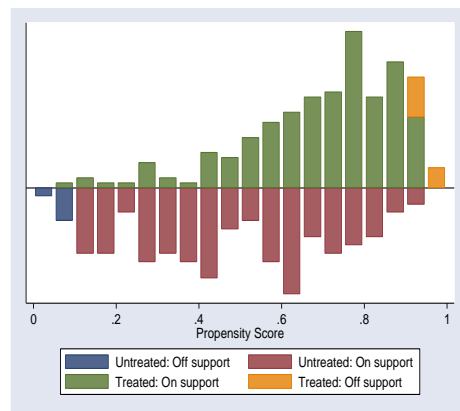

(a)

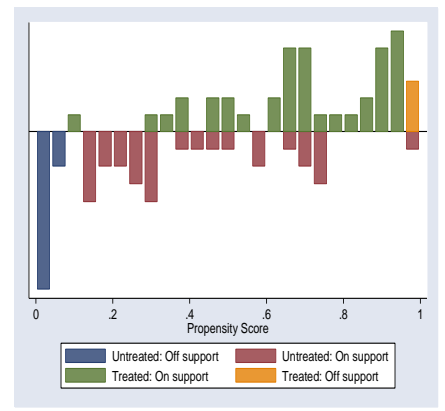

(b)

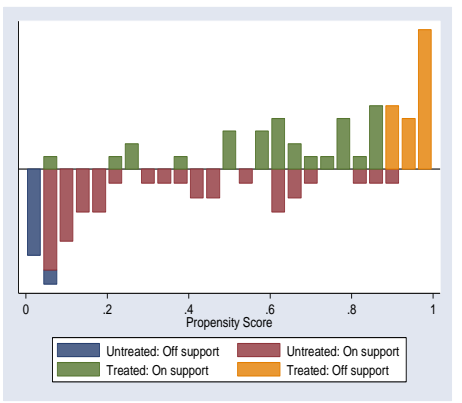

(c)

Figure 2. Indicators of the covariates balancing before and after matching; (a) impact on household income; (b) impact on wheat cost of production; (c) impact on rice cost of production.

\section{Conclusions}

Human capital, i.e., wealth and education level of the farmer, drives the increase in the amount of fertilizers applied such as urea, DAP, and farmyard manure, as it reflects the affordability and awareness of the fertilizer usage and yield. As a result of the fertilizer subsidy, more than $60 \%$ of the farmers increased fertilizer application. The increased fertilizer application has positively impacted the yield of two most important food crops, i.e., wheat and rice and associated household income levels. However, the farmers need to be guided about the recommended application of the fertilizer as overdose also has a negative impact, such as increased inputs cost. Also, the balance between farmyard manure and the chemical fertilizers is very important. As the results of the recent subsidy program in Pakistan show, the farmers have decreased the use of farmyard manure while they have increased the use of chemical fertilizer. However, the fertilizer subsidy program needs to be linked with training from the extension workers and other agriculture agents on the four principals for fertilizer application, namely right fertilizer source, right rate, at the right time, and in the right place. For the conservation of natural resources and soil and water conservation, the use of farmyard manure and leguminous crops needs to be increased.

Author Contributions: A.A., Conceptualization, Methodology, Data Collection, Data Analysis, Initial Draft Writeup; D.B.R., Writing Review and Editing, Supervision; M.I., Writing Review and Editing, Supervision.

Funding: The current study was funded by USAID funded Agricultural Innovation Program (AIP) for Pakistan.

Conflicts of Interest: The authors declare no conflict of interest.

\section{References}

1. Government of Pakistan. Pakistan Economic Survey 2016-2017, Agriculture; Ministry of Finance: Islamabad, Pakistan, 2016.

2. Government of Pakistan. Pakistan Economic Survey 2007-2008, Agriculture; Ministry of Finance: Islamabad, Pakistan, 2007.

3. Krauss, G.D.; Page, A.L. Wastewater, sludge and food crops. BioCycle (USA) 1997, 38, 74-82.

4. APO. Impact of Agricultural Practices on Environmental Sustainability in Asia; Asian Productivity Organization: Tokyo, Japan, 2002.

5. Afzal, N.; Ahmad, S. Agricultural input use efficiency in Pakistan: Key issues and reform areas. Manag. Nat. Resour. Sustain. Future Agric. 2009, 1, 1-12.

6. Holden, S.; Lunduka, R. Too Poor to be Efficient? Impact of Targeted Fertilizer Subsidy Program in Malawi on Farm Plot Level Input Use, Crop Choice and Land Productivity; Norwegian University of Life Sciences: Ås, Norway, 2010.

7. Chibwana, C.; Fisher, M.; Shively, G. Cropland Allocation Effects of Agricultural Input Subsidies in Malawi. World Dev. 2012, 40, 124-133. [CrossRef] 
8. Khan, H.G.A.; Ahmad, A.; Awais, S. Impact of Rising Prices of Fertilizers on Crops Production in Pakistan. Glob. J. Manag. Bus. Res. 2010, 9, 54-61.

9. Ali, A.; Sharif, M. Impact of farmer field schools on adoption of integrated pest management practices among cotton farmers in Pakistan. J. Asia Pac. Econ. 2012, 17, 498-513. [CrossRef]

10. Ali, A.; Sharif, M. Impact of integrated weed management on cotton producers 'earnings in Pakistan. Asian Economic J. 2011, 25, 413-428. [CrossRef]

11. Gabre-Madhin, E. A Market for All Farmers: Market Institutions and Small Holders' Participation. UC Berkeley. 2009. Available online: https://escholarship.org/uc/item/3k49r747 (accessed on 11 September 2019).

12. Quddus, M.A.; Siddiqi, M.W.; Riaz, M. The demand for nitrogen, phosphorus and potash fertilizers nutrient in Pakistan. Pak. Econ. Soc. Rev. 2008, 46, 101-116.

13. Crawford, E.W.; Jayne, T.S.; Kelly, V.A. Alternative Approaches for Promoting Fertilizer Use in Africa; Agriculture \& Rural Development Department, World Bank: Washington, DC, USA, 2006.

14. Hazell, P.B.R.; Poulton, C.; Wiggins, S.; Dorward, A. The Future of Small Farms for Poverty Reduction and Growth; International Food Policy Research Institute: Washington, DC, USA, 2007.

15. Ajah, T.; Nmadu, J.N. Small Scale maize farmers access to Farm inputs in Abuja, Nigeria, Kasetsart. J. Soc. Sci. 2012, 33, 499-505.

16. Govinindan, K.; Babu, S.C. Supply response under market liberalization: A case study of Malawian Agriculture. Dev. South. Afr. 2001, 18, 93-106. [CrossRef]

17. Bunde, A.O.; Kipkemoi, K.; Daphen, O.O.; Mugo, S.W. Impact of Fertilizer Input Subsidy on Maize Production in Nandi, North District, Kenya. Int. J. Sci. Basic Appl. Res. 2014, 15, 520-540.

18. Sibande, L.; Bailey, A.; Davidova, S. The impact of farm input subsidies on household welfare in Malawi, Agriculture in inter connected world. Int. Assoc. Agric. Econ. 2014. [CrossRef]

19. Warr, P.; Yusuf, A.A. Fertilizer Subsidies and Food Self Sufficiency in Indonesia. Agric. Econ. 2014, 45, 571-588. [CrossRef]

20. Mapila, J.J. The Impact of Alternate Input Subsidy Exit Strategies in Malawi's Maize Community Market, Discussion Paper; IFPRI: Washington, DC, USA, 2013.

21. Caliendo, M.; Kopeinig, S. Some Practical guidance for the implementation of Propensity Score Matching. J. Econ. Surv. 2008, 22, 31-72. [CrossRef]

22. Ali, A.; Abdulai, A. The adoption of genetically modified cotton and poverty reduction in Pakistan. J. Agric. Econ. 2010, 61, 175-192. [CrossRef]

23. Ali, A.; Rahut, D.B.; Behera, B. Factors influencing farmers' adoption of energy-based water pumps and impacts on crop productivity and household income in Pakistan. Renew. Sustain. Energy Rev. 2016, 2, 48-57. [CrossRef]

24. Ali, A.; Erenstein, O. Assessing farmer use of climate change adaptation practices and impacts on food security and poverty in Pakistan. Clim. Risk Manag. 2017, 16, 183-194. [CrossRef]

(C) 2019 by the authors. Licensee MDPI, Basel, Switzerland. This article is an open access article distributed under the terms and conditions of the Creative Commons Attribution (CC BY) license (http://creativecommons.org/licenses/by/4.0/). 